\title{
PENGARUH EVA DAN MVA TERHADAP RETURN SAHAM PADA PERUSAHAAN TERGABUNG 169 IDX3O DI BEI
}

\author{
Andi Raharjo', Rusdi Hidayat $\mathbf{N}^{\mathbf{2}}$ \\ Fakultas Ilmu Sosial dan Ilmu Politik Universitas Pembangunan "Veteran” Jawa Timur 1,2 \\ andiraharjo04@gmail.com $^{1}$; $\underline{\text { rusdi hidayat.adbis@upnjatim.ac.id }}^{2}$
}

\begin{abstract}
ABSTRAK
Latar belakang investor menginvestasikan hartanya di pasar modal ialah untuk mendapatkan pundi-pundi keuntungan. Dalam konteks investasi, tinkat keuntungan investasi disebut sebagai return. Sedangkan pendapatan yang diharapkan oleh investor (return) ialah deviden dan capital gain. Deviden berfungsi untuk mengukur jumlah deviden per lembar saham terhadap harga saham dalam bentuk presentase sehingga semakin tinggi Devidend Yield, maka investor akan semakin tertarik untuk membeli saham tersebut karena untung. Analisis yang sering digunakan oleh perusahaan dalam pengukuran kinerjanya adalah analisis rasio keuangan. Meskipun analisis rasio keuangan digunakan oleh investor Sebagai alat ukur konvensional, kekurangan utama dari analisis rasio ini adalah mengabaikan biaya modal, maka dari itu sulit untuk mengetahui apakah perusahaan berhasil menciptakan nilai sebuah perusahaan di mata investor atau tidak. Maka dari itu, konsep Economic Value Added (EVA) dan Market Value Added (MVA) digunakan sebagai metode pengukuran kinerja keuangan dan pasar untuk mengatasi kekurangan dari rasio keuangan yang biasanya dipakai oleh investor. Penelitian menggunakan metode kuantitatif, data sekunder yang diperoleh dari website BEIyaitu data keuangan perusahaan yang tergabung di IDX30 yang listing di BEI periode 2016-2018. Metode analisis data menggunakan Uji asumsi klasik. Metode uji hipotesis menggunakan regresi linear berganda. Populasi yang digunakan yaitu keseluruh perusahaan yang tergabung di IDX30, sedangkan sampel yang diambil diperoleh 12 perusahaan periode 2016-2018. Berdasarkan hasil penelitian, EVA menunjukkan pengaruh negatif dan tidak signifikan terhadap Return Saham, Sedangkan MVA menunjukkan pengaruh positif dan signifikan terhadap Return Saham. Dari hasil Uji F menunjukkan bahwa kedua variabel (EVA dan MVA) menunjukkan pengaruh secara simultan terhadap Return Saham
\end{abstract}

Kata Kunci : EVA, MVA, Return Saham

\section{Abstract}

The background of investors investing their assets in the capital market is to get coffers of profits. In the context of investment, the rate of return on investment is referred to as return. Meanwhile, the income expected by investors (return) is dividends and capital gains. Dividend serves to measure the amount of dividend per share against the share price in the form of a percentage so that the higher the Devidend Yield, the more interested investors will be to buy these shares because of profits. The analysis that is often used by companies in measuring their performance is financial ratio analysis. Although financial ratio analysis is used by investors as a conventional measuring tool, the main drawback of this ratio analysis is that it ignores the cost of capital, therefore it is difficult to know whether the company has succeeded in creating a company's value in the eyes of investors or not. Therefore, the concept of Economic 
Value Added (EVA) and Market Value Added (MVA) is used as a method of measuring financial and market performance to overcome the shortcomings of financial ratios that are usually used by investors. This research uses quantitative methods, secondary data obtained from the IDX website, namely the financial data of companies incorporated in IDX3O which are listed on the IDX for the 2016-2018 period. The data analysis method used the classical assumption test. Hypothesis testing method uses multiple linear regression. The population used is all companies that are members of the IDX30, while the samples taken were obtained from 12 companies for the 20162018 period. Based on the research results, EVA shows a negative and insignificant effect on Stock Returns, while MVA shows a positive and significant effect on Stock Returns. From the results of the F test shows that the two variables (EVA and MVA) show a simultaneous influence on Stock Return.

Keywords: Economic Value Added, Market Value Added, Stock Return

Diterima: 30 Maret 2021; Direvisi: 6 April 2021; Diterbitkan: 1 April 2021

\section{PENDAHULUAN}

Latar belakang investor menginvestasikan hartanya di pasar modal ialah untuk mendapatkan pundi-pundi keuntungan. Dalam konteks investasi, tinkat keuntungan investasi disebut sebagai return. Sedangkan pendapatan yang diharapkan oleh investor (return) ialah deviden dan capital gain. Deviden (Devidend yield) berfungsi untuk mengukur jumlah deviden per lembar saham terhadap harga saham dalam bentuk presentase sehingga semakin tinggi Devidend Yield, maka investor akan semakin tertarik untuk membeli saham tersebut karena untung.

Pasar modal (capital market) merupakan pasar dimana individu, pemerintah, dan perusahaan tidak dapat dengan segera mentransfer uang untuk kebutuhan individu, pemerintah dan perusahaan. Perusahaan membutuhkan keuangan dalam jangka waktu yang pendek misalnya untuk membel bahan baku untuk produksi atau sedang menunggu untuk dibayar oleh pelanggan atau masih harus tetap membayar karyawan. Dengan demikian sebagian besar mereka akan melakukan peminjaman bank (Rusdi Hidayat, 2017:171)
Analisis yang sering digunakan oleh perusahaan dalam pengukuran kinerjanya adalah analisis rasio keuangan. Meskipun analisis rasio keuangan digunakan oleh investor Sebagai alat ukur konvensional, kekurangan utama dari analisis rasio ini adalah mengabaikan biaya modal. Sehingga konsep Economic Value Added (EVA) dan Market Value Added (MVA) dapat digunakan untuk menilai kinerja keuangan dan pasar yang merupakan kelemahan rasio keuangan berdasarkan nilai yang dimiliki perusahaan.

Di Bursa Efek Indonesia terdapat 30 perusahaan yang terdaftar di IDX30. Dari 30 perusahaan tersebut kemudian hanya 12 perusahaan yang dijadikan sebagai objek penelitian tentang faktor fundamental yang dapat mempengaruhi return saham di perusahaan tersebut, yaitu konsep investasi yang terdiri dari EVA dan MVA. Konsep investasi ini memberikan tolak ukur kinerja sebuah perusahaan serta kondisi keuangan perusahaan yang mana tidak bisa dipecahkan oleh rasio keuangan.

Berdasarkan informasi yang diperoleh dari website Bursa Efek Indonesia, alasan penulis memilih IDX30 daripada LQ45 adalah aslinya pengertian antara keduanya sama, akan tetapi IDX30 
lebih mengkerucut dalam hal perusahaan yang memiliki tingkat likuiditas yang lebih tinggi (top) sehingga penulis berusaha membuktikan apakah perusahaan yang tergabung di Indeks IDX30 memiliki nilai dan cocok untuk digunakan ladang investasi.

\section{LANDASAN TEORI}

\section{Manajemen Keuangan}

Menurut James C.Van Horne dikutip dari buku Kasmir (2015:5), mendefinisikan manajemen keuangan adalah segala aktifitas yang berhubungan dengan perolehan, pendanaan, dan pengelolaan aktiva dengan beberapa tujuan menyeluruh. Dari definisi tersebut dapat diartikan bahwa kegiatan manajemen keuangan adalah berkutat disekitar:

1. Bagaimana memperoleh dana untuk membiayai usahanya.

2. Bagaimana mengelola dana tersebut sehingga tujuan perusahaan tercapai.

3. Bagaimana perusahaan mengelola aset yang dimiliki secara efisien dan efektif.

Menurut Brigham, manajemen keuangan adalah seni (art) dan ilmu (science), untuk me-manage uang, yang meliputi proses, institusi/lembaga, pasar, dan instrumen yang terlibat dengan masalah transfer uang diantara individu, bisnis, dan pemerintah. Dari pengertian tersebut dapat disimpulkan bahwa kegiatan pengelolaan keuangan berkaitan erat dengan pengelolaan keuangan perusahaan, termasuk kelembagaan yang berkaitan erat dengan sumber dana, investasi keuangan perusahaan dan instrumen keuangan.

\section{Laporan Keuangan}

Menurut Kasmir (2015:7) dalam pengertian yang sederhana, laporan keuangan adalah laporan yang menunjukkan kondisi keuangan perusahaan pada saat ini atau dalam suatu periode tertentu. Tujuan laporan keuangan yang dapat menunjukkan status keuangan perusahaan saat ini adalah statusnya saat ini. Status perusahaan saat ini adalah status keuangan perusahaan pada tanggal tertentu (untuk neraca) dan periode tertentu (untuk laporan laba rugi). Laporan keuangan menggambarkan prospek keuangan perusahaan selama periode waktu tertentu. (Soehardi et al., 2020)

\section{Analisis Laporan Keuangan}

Menurut Kasmir (2013:66), analisis laporan keuangan merupakan kegiatan yang dilakukan setelah laporan keuangan disusun berdasarkan data yang relevan, serta dilakukan dengan prosedur akuntansi dan penilaian yang benar, akan terlihat kondisi keuangan perusahaan yang sesungguhnya.

Secara umum, analisis laporan keuangan perusahaan pada dasarnya untuk menghitung rasio untuk mengevaluasi status keuangan untuk membantu mengevaluasi status keuangan perusahaan saat ini dan masa lalu serta hasil operasi. Tujuannya adalah untuk menentukan perkiraan dan prakiraan yang paling mungkin tentang hal-hal berikut: Kondisi dan kinerja, serta masa depan.

\section{Saham}

Saham sekuritas surat berharga yang yang mewakili kepemilikan dalam sebuah perusahaan dan memiliki klaim pada bagian dari asset perusahaan dan laba per saham (Guinan, 2010: 341).

Saham adalah tanda bukti penyertaan kepemilikan modal/ dana pada suatu perusahaan. kertas yang tercantum dengan jelas nilai nominal, nama 
perusahaan dan diikuti dengan hak dan kewajiban yang dijelaskan kepada setiap pemegangnya (Fahmi, 2012: 81)

\section{Return Saham}

Hartono (2010) menyatakan bahwa "Return merupakan hasil yang di peroleh dari investasi", Pengembalian dapat berupa pengembalian yang direalisasikan (realized) atau pengembalian yang diharapkan (expected). Pengembalian yang direalisasikan dihitung berdasarkan data historis. Menyadari manfaat menjadi sangat penting karena dapat dijadikan sebagai tolak ukur kinerja perusahaan. Return yang diharapkan merupakan return yang diharapkan investor dimasa yang akan datang, sehingga ekspektasi return tersebut belum terjadi. Oleh karena itu, return adalah pendapatan investasi perusahaan yang dicatatkan di pasar modal oleh investor dalam bentuk deviden atau capital gain and loss (berdasarkan harga saham).

\section{Economic Value Added (EVA)}

Menurut Wijaya dan Tjun (2009), "Economic Value Added adalah indikator internal yang mengukur kekayaan pemegang saham suatu perusahaan dalam jangka waktu tertentu. EVA mengukur seberapa efisien perusahaan menggunakan modalnya untuk menciptakan nilai tambah ekonomis. Nilai tambah ekonomis tercipta jika perusahaan menghasilkan return on total capital yang melebihi cost of capital”. Lebih jelasnya laba operasi bersih setelah pajak (NOPAT) dikurangi biaya modal yang digunakan untuk modal. Disarankan agar NOPAT disesuaikan untuk mencerminkan metode kas daripada basis akrual untuk mencerminkan kinerja perusahaan.

Market Value Added (MVA)
Menurut Brigham \& Houston (2010), Market Value Added (MVA) adalah selisih antara nilai pasar atas sebuah modal suatu perusahaan dengan nilai buku seperti disajikan dalam neraca. Lebih jelasnya nilai pasar (total market value) dari semua saham dan obligasi perusahaan, yang artinya jika semua saham dan obligasinya dijual ke pasar keuangan, berapa pendapatan yang akan didapat investor dikurangi total modal investasi (dalam ekuitas).

\section{IDX30}

IDX30 merupakan indeks yang mengukur kinerja harga 30 saham dengan likuiditas tinggi, kapitalisasi pasar besar, dan fundamental perusahaan yang baik.

Dalam proses ini, 45 jenis saham paling likuid (LQ-45) disaring dari IHSG, kemudian disaring lagi 30 jenis saham dari 45 jenis saham tersebut yang disebut IDX30. Oleh karena itu, anggota saham yang menjadi anggota IDX30 juga merupakan anggota LQ-45.

Walaupun secara definisi, salah satu kriterianya adalah saham berfundamental baik, dari pengamatan dan praktek, kelihatannya porsi likuiditas dan kapitalisasi pasar lebih banyak menjadi faktor utama.

Yang dimaksud dengan likuiditas adalah transaksi jual beli di pasar reguler. Likuiditas yang tinggi artinya saham tersebut sangat aktif ditransaksikan. Didukung dengan kapitalisasi (ukuran perusahaan) yang besar, anggota saham dalam IDX-30 dan LQ-45 biasanya juga merupakan saham yang banyak ditransaksikan oleh investor asing.

\section{Kerangka Berpikir}




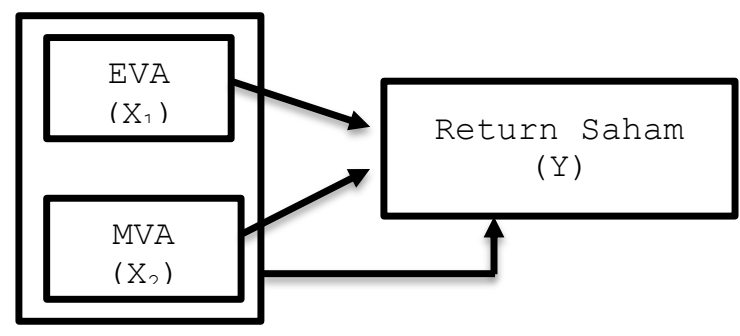

\section{Hipotesis}

1. Economic Value Added (EVA) dan Market Value Added (MVA) secara simultan berpengaruh terhadap Return saham pada perusahaan tergabung di IDX30 yang terdaftar di Bursa Efek Indonesia.

2. Economic Value Added (EVA) dan Market Value Added (MVA) secara Parsial berpengaruh terhadap Return saham pada perusahaan tergabung di IDX30 yang terdaftar di Bursa Efek Indonesia.

3. EVA dan MVA secara Simultan tidak berpengaruh terhadap Return saham pada perusahaan tergabung di IDX30 yang terdaftar di Bursa Efek Indonesia.

4. Economic Value Added (EVA) dan Market Value Added (MVA) secara Parsial tidak berpengaruh terhadap Return saham pada perusahaan tergabung di IDX30 yang terdaftar di Bursa Efek Indonesia.

\section{METODE PENELITIAN}

\section{Jenis Penelitian}

Penelitian ini merupakan penelitian kuantitatif dengan menganalisa data sekunder. Penelitian kuantitatif adalah sebagai metode penelitian yang berlandaskan pada filsafat positivisme, digunakan untuk meneliti pada populasi atau sampel tertentu, teknik pengambilan sampel pada umumnya dilakukan secara random, pengumpulan data menggunakan instrumen penelitian, analisis data bersifat kuantitatif atau statistik dengan tujuan untuk menguji hipotesis yang telah ditetapkan (Sugiyono, 2013:14).

\section{Populasi dan Sampel}

Populasi dalam penelitian ini dalah seluruh peruahaan yang tergabung di IDX30 yang terdaftar di Bursa Efek Indonesia (BEI) yang berjumlah tiga puluh (30) perusahaan sedangkan metode penarikan sampel menggunakan metode non-probability sampling yaitu purposive sampling. Sehingga terdapat populasi yang tidak memenuhi kriteria, maka tidak bisa dijadikan objek penelitian. Dari 30 Perusahaan yang terdaftar, terpilih 12 perusahaan yang memenuhi kriteria bagi peneliti sebagai objek penelitian periode 2016-2018. Sehingga total terdapat 36 sampel hasil dari 12 perusahaan dikali 3 tahun (periode 2016-2018).

\begin{tabular}{|l|l|}
\multicolumn{2}{|c}{ Tabel 1. Daftar Perusahaan yang dijadikan sampel } \\
\hline No & Nama Perusahaan \\
\hline 1 & Adaro Energy Tbk. \\
\hline 3 & Bumi Serpong Damai Tbk. \\
\hline 4 & Gudang Garam Tbk. \\
\hline 5 & Indofood CBP Sukses Makmur Tbk \\
\hline 6 & Indofood Sukses Makmur Tbk. \\
\hline 7 & Indocement Tunggal Prakasa Tbk. \\
\hline 8 & Kalbe Farma Tbk. \\
\hline 9 & Matahari Departement Store Tbk. \\
\hline 10 & Perusahaan Gas Negara (Persero) Tbk. \\
\hline 11 & Telekomunikasi Indonesia (Persero) Tbk. \\
\hline 12 & Unilever Indonesia Tbk. \\
\hline
\end{tabular}

\section{Teknik Pengumpulan Data}

Dalam penelitian ini menggunakan metode dokumentasi yaitu mengkopi, mencatat, mempelajari dan menganalisis Financial Data and Ratio dari Bursa Efek Indonesia yang terdiri dari Laporan Neraca 
dan Laporan Laba Rugi Perusahaan IDX30 pada periode 31 Desember 2016 sampai dengan 31 Desember 2018 (tiga tahun).

\section{HASIL PENELITIAN PEMBAHASAN}

\section{Asumsi Klasik}

Digunakan untuk menguji apakah model regresi layak digunakan dalam penelitian ini. Tujuan utama penggunaan pengujian hipotesis klasik adalah untuk mendapatkan koefisien regresi linier dan tidak bias terbaik (BLUE : Best Linier Unbiased Estimator).

Suatu model dikatakan BLUE, bila memenuhi persyaratan sebagai berikut :

a. Tidak boleh ada multikolinieritas.

b. Tidak boleh ada heterokedastisitas.

c. Tidak boleh ada autokorelasi.

Jika salah satu asumsi dasar tersebut dilanggar maka persamaan regresi yang diperoleh tidak lagi BLUE, sehingga keputusan yang lolos uji f dan uji t akan bias.

\section{Uji Multikolinearitas}

Identifikasi secara statistik ada atau tidaknya gejala Multikolinieritas dapat dilakukan dengan menggunakan uji efisiensi korelasi (r). Jika koefisien korelasi cukup tinggi, yaitu di atas 0.90, maka diduga terjadi multikolinearitas dalam model. Sebaliknya, jika koefisien relatif rendah maka diduga model tidak terjadi multikolinearitas.

Tabel 2. Tabel multikolinearitas Correlation

\begin{tabular}{|ccc|}
\hline & $\mathrm{X} 1$ & $\mathrm{X} 2$ \\
\hline \hline $\mathrm{X} 1$ & 1.000000 & 0.693770 \\
$\mathrm{X} 2$ & 0.693770 & 1.000000 \\
\hline
\end{tabular}

(Sumber: Olah data Eviews 9)
Dari tabel diatas menunjukan bahwa hasil pengujian multikolinieritas melalui $r$, diperoleh hasil nilai $r$ untuk variabel EVA $\left(\mathrm{X}_{1}\right)$ dan MVA (X2) tidak ada yang lebih besar dari 0,9 sehingga dapat disimpulkan bahwa model regresi ini tidak terjadi gejala multikolinieritas.

\section{Uji Heteroskedastisitas}

Uji heteroskedastisitas dilakukan untuk mengetahui apakah dalam sebuah model regresi terjadi ketidaksamaan varians dari residual suatu pengamatan ke pengamatan lain.

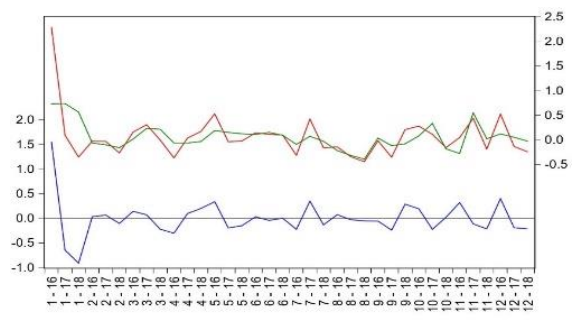

- Residual _- Actual — Fitted

Gambar 1. Grafik Heterokedastisitas

(Sumber: Olah data Eviews 9)

Pada penelitian ini setelah dilakukan uji heterokodestisitas, maka hasilnya menunjukan berupa grafik yang terlihat tidak membentuk pola tertentu. Hal tersebut menunjukan bahwa hasil penelitian tidak terjadi gejala heterokodestisitas sehingga model regresi yang digunakan layak dipakai.

\section{Uji Autokorelasi}

Uji autokorelasi bertujuan untuk mengetahui apakah dalam sebuah model regresi linier ada kolerasi antara data pengamatan atau tidak. Untuk mendeteksi gejala autokorelasi dapat menggunakan uji Durbin-Watson.

Tabel 3. Hasil Uji Autokorelasi D-W
\begin{tabular}{|llll|}
\hline \multicolumn{4}{|c|}{ Weighted Statistics } \\
\hline \hline R-squared & 0.830794 & Mean dependent var & -0.021045 \\
Adjusted R-squared & 0.730808 & S.D. dependent var & 0.902805 \\
S.E. of regression & 0.468385 & Sum squared resid & 4.826457 \\
F-statistic & 8.309127 & Durbin-Watson stat & 2.574504 \\
Prob(F-statistic) & 0.000010 & & \\
\hline
\end{tabular}
(Sumber: Olah data Eviews 9)


Dari hasil output di atas didapat nilai DW yang dihasilkan dari model regresi adalah 2.574. Dengan demikian, membuktikan bahwa tidak terjadi autokorelasi karena menurut tabel DurbinWatson memiliki dU sebesar 1.584 dan $\mathrm{dL}$ sebesar 1.354. Sehingga dU $<\mathrm{dW}=1.584$ $<2.574$ membuktikan tidak adanya autokorelasi.

\section{Uji Normalitas}

Uji normalitas bertujuan untuk menguji apakah dalam model regresi, variabel terikat dan variabel beas keduanya mempunyai distribusi normal ataukah tidak. Kenormalan suatu data dapat dilihat dengan analisis grafik dan uji statistik. Namun dalam penelitian ini lebih ditekankan untuk menguji dengan uji statistik. Uji statistik yang dilakukan adalah dengan uji Jarque-Bera (JB). Akan tetapi data yang digunakan adalah data acak maka harus dilakukan pembobotan agar data distribusi normal.

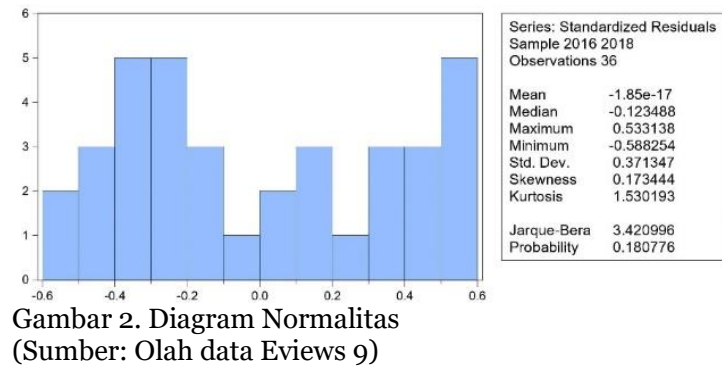

Dari gambar tersebut, nilai probability sebesar $0.18>0.05$ sehingga dapat ditarik kesimpulan bahwa data memiliki distribusi normal.

\section{Analisis Regresi Linear Berganda}

Tabel 4. Hasil Uji Analisis Regresi Linear Berganda

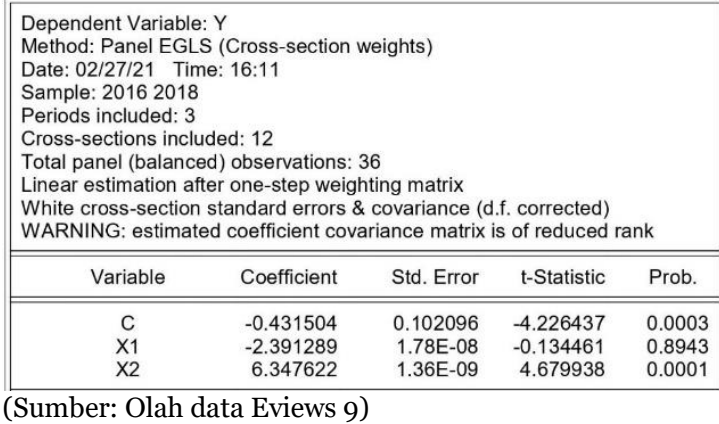

(Sumber: Olah data Eviews 9)

Dari hasil perhitungan diatas, maka persamaan regresi linier berganda sebagai berikut :

$\mathrm{Y}=\alpha+\beta_{1} \mathrm{X}_{1}+\beta_{2} \mathrm{X}_{2}+\mathrm{e}$

$\mathrm{Y}=-0.431+(-2.391289 \mathrm{EVA})+$ 6.347622 MVA + e

Hasil perhitungan statistik menunjukan bahwa variabel yang mempunyai parameter koefisien bertanda negatif. Secara matematis tanda negatif berarti setiap perubahan salah satu variabel bebas akan mengakibatkan perubahan variabel tidak bebas dengan arah yang berlawanan apabila variabel lainnya dianggap konstan. Sehingga dari persamaan diatas dapat dijelaskan sebagai berikut :

1. Konstan a sebesar -0.431 artinya jika variabel Economic Value Added (EVA), dan Market Value Added (MVA) masing- masing memiliki nilai konstan (tetap), maka kenaikan 1 satuan akan mengurangi Return saham perusahaan yan tergabung di IDX30 di Bursa Efek Indonesia sebesar -0.431.

2. Koefisien regresi Economic Value Added $\quad\left(\mathrm{X}_{1}\right) \quad$ sebesar $\quad-2.391289$ menunjukan bahwa ketika Economic Value Added ( $\left.\mathrm{X}_{1}\right)$ meningkat sebesar 1 satuan, maka akan mengurangi Return Saham sebesar -2.391289. Dengan anggapan variabel bebas lainnya konstan.

3. Koefisien regresi Market Value Added $\left(\mathrm{X}_{2}\right)$ sebesar 6.347622 menunjukan bahwa ketika Market Value Added $\left(\mathrm{X}_{2}\right)$ 
meningkat sebesar 1 satuan, maka akan meningkatkan Return Saham sebesar 6.347622. Dengan anggapan variabel bebas lainnya konstan.

\section{Uji Hipotesis}

\section{Uji F (Simultan)}

Digunakan untuk mengetahui pengaruh dari semua variabel bebas terhadap variabel terikat secara simultan atau bersama.

Tabel 5. Hasil Uji F

\begin{tabular}{|lrlr|}
\hline \multicolumn{4}{|c|}{ Weighted Statistics } \\
\hline \hline R-squared & 0.830794 & Mean dependent var & -0.021045 \\
Adjusted R-squared & 0.730808 & S.D. dependent var & 0.902805 \\
S.E. of regression & 0.468385 & Sum squared resid & 4.826457 \\
F-statistic & 8.309127 & Durbin-Watson stat & 2.574504 \\
Prob(F-statistic) & 0.000010 & & \\
\hline
\end{tabular}

(Sumber: Olah data Eviews 9)

Menentukan level of signifikan (a) dengan rumus $\mathrm{Df}=\mathrm{k} ; \mathrm{n}-\mathrm{k}$ dimana tarif signifikan 0,05 dengan derajat kebebasan (df) 2:34, sehingga $F_{\text {tabel }}=3,28$.

Dari hasil pengolahan data menggambarkan Eviews 9, dapat diketahui bahwa Fhitung sebesar 8.309.

Sehingga bisa ditarik kesimpulan bahwa nilai $\mathrm{F}_{\text {hitung }}(8,309)>\mathrm{F}_{\text {tabel }}(3,28)$ sehingga $\mathrm{H}_{\mathrm{o}}$ ditolak dan $\mathrm{H}_{1}$ diterima. Hal ini berarti variabel EVA $\left(\mathrm{X}_{1}\right)$, dan MVA (X2) secara bersama-sama mempunyai pengaruh simultan terhadap return saham (Y) perusahaan yang tergabung di IDX30 yang terdaftar di BEI.

\section{Uji t (Parsial)}

Uji $t$ digunakan untuk menguji pengaruh variabel-variabel bebas secara parsial terhadap variabel terikat dengan pengujian secara mandiri.

\begin{tabular}{|c|c|c|c|c|}
\hline Variable & Coefficient & Std. Error & $\mathrm{t}$-Statistic & Prob. \\
\hline C & -0.431504 & 0.102096 & -4.226437 & 0.0003 \\
\hline $\mathrm{X} 1$ & -2.391289 & $1.78 \mathrm{E}-08$ & -0.134461 & 0.8943 \\
\hline$x 2$ & 6.347622 & 1.36E-09 & 4.679938 & 0.0001 \\
\hline
\end{tabular}

Menentukan level of significant $(\alpha)$ dengan rumus $\mathrm{Df}=\mathrm{n}-\mathrm{k}-1$, dimana taraf signifikan 0,$05 ; 2=0,025$ (uji dua sisi) dengan derajat kebebasan (df) 33, sehingga diperoleh $t_{\text {tabel }}=2.034$

\section{Uji Parsial Variabel EVA}

$$
\begin{aligned}
& \text { Daerah penolakan } \mathrm{H} 0 \\
& -\mathrm{t}_{\text {tabel }}=-2.034 \quad \mathrm{t}_{\text {hitung }}=-0.134 \quad \mathrm{t}_{\text {tabel }}= \\
& 2.034
\end{aligned}
$$

\section{Uji Parsial Variabel MVA}

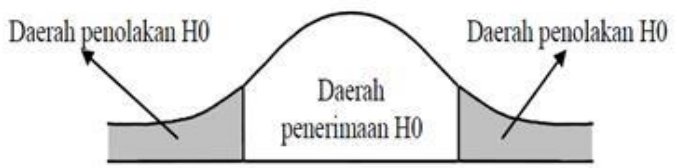

$$
\begin{gathered}
-t_{\text {tabel }}=-2.034 t_{\text {hitung }}=4.679 t_{\text {tabel }}=2.034 \\
\text { Gambar 4. Kurva Daerah Penerimaan dan Penolakan } \\
H_{0} \text { Uji t Variabel MVA }
\end{gathered}
$$

Berdasakan kurva diatas menunjukan bahwa nilai thitung $(4.679) \geq$ tabel (2.034) maka $\mathrm{H}_{\mathrm{o}}$ ditolak dan $\mathrm{H}_{1}$ diterima, berarti variabel MVA $\left(\mathrm{X}_{2}\right)$ secara parsial memiliki pengaruh terhadap Return Saham (Y) pada perusahaan yang tergabung di IDX30 di BEI. 


\section{Koefisien Determinasi}

\begin{tabular}{|lrlr|}
\multicolumn{4}{c|}{ Tabel 7. Tabel R ${ }^{2}$} \\
\hline \multicolumn{4}{c|}{ Weighted Statistics } \\
\hline \hline R-squared & 0.830794 & Mean dependent var & -0.021045 \\
Adjusted R-squared & 0.730808 & S.D. dependent var & 0.902805 \\
S.E. of regression & 0.468385 & Sum squared resid & 4.826457 \\
F-statistic & 8.309127 & Durbin-Watson stat & 2.574504 \\
Prob(F-statistic) & 0.000010 & & \\
\hline \multicolumn{4}{|c|}{ (Sumber: Olah data Eviews 9) } \\
\hline
\end{tabular}

Nilai koefisien determinasi atau $\mathrm{R}^{2}$ digunakan untuk mengukur seberapa besar persentase variabel bebas yang digunakan dalam model dapat mempengaruhi variabel terikat (Y) yaitu Return Saham. Dari hasil analisis linier berganda diperoleh nilai $\mathrm{R}^{2}=$ o,8307 yang berarti bahwa sebesar 83,07\% Return saham dapat dipengaruhi oleh variabel Economic Value Added $\left(\mathrm{X}_{1}\right)$, dan Market Value Added (X2). Sedangkan sisanya $16,93 \%$ dipengaruhi oleh variabel lain yang tidak dimasukan dalam model penelitian ini.

\section{KESIMPULAN DAN SARAN}

\section{Kesimpulan}

Berdasarkan hasil penelitian dan pembahasan maka dapat ditarik kesimpulan sebagai berikut:

1. Variabel $E V A\left(\mathrm{X}_{1}\right)$ dan $M V A\left(\mathrm{X}_{2}\right)$ secara bersama (simultan) mempunyai pengaruh terhadap Return saham (Y) perusahaan yang tergabung di IDX30 di BEI.

2. Hasil analisis pengujian secara parsial dapat ditarik kesimpulan sebagai berikut:

a. Economic Value Added (EVA) berpengaruh negatif serta tidak signifikan terhadap Return Saham pada perusahaan yang tergabung di IDX30 yang terdaftar di BEI.

b. Market Value Added (MVA) berpengaruh positif serta signifikan terhadap Return Saham pada perusahaan yang tergabung di IDX30 yang terdaftar di BEI.

\section{Saran}

1. Bagi calon investor yang akan berinvestasi dapat mempertimbangkan aspek kedua variabel ini (EVA dan MVA) akan tetapi dapat lebih condong ke MVA karena memiliki hasil pengaruh positif serta signifikan terhadap Return Saham.

2. Bagi peneliti selanjutnya, sebaiknya disarankan untuk melakukan kajian lebih lanjut tentang rasio profitabilitas maupun rasio keuangan yang lain sebagai tambahan untuk variabel bebas lainnya seperti ROA, ROE, EPS, dll.

3. Bagi peneliti selanjutnya, sebaiknya menambah periode penelitian yang akan digunakan, sehingga akan mampu diperoleh hasil yang lebih baik mengenai Return saham di BEI

\section{Daftar Pustaka}

Ansori. (2015). Pengaruh Economic Value Added Dan Market Value Added Terhadap Return Saham Pada Perusahaan Manufaktur Yang Terdaftar Di Bursa Efek Indonesia. Program Studi Manajemen,Universitas Negeri Yogyakarta 2015

Eugene F. Brigham dan Houston. (2010). Fundamental of Financial Management: Dasar Dasar Manajemen Keuangan. Jakarta: Salemba Empat

Fahmi, Irham. (2012). Pengantar Pasar Modal. Bandung : CV. Alfabeta

Febby Ferinda. (2019). Pengaruh Economic Value Added Dan Market Value Added Terhadap Return Saham Pada Perusahaan Yang Terdaftar Di Jakarta Islamic Index Periode 20152017. Program Studi Perbankan Syariah, Universitas Islam Negeri Raden Intan Lampung 2019. Ghozali, Imam. (2013). Aplikasi Analisis 
Multivariate Dengan Program: IBM SPSS 21 Update PLS Regresi. Cetakan VII. Badan Penerbit Universitas Diponegoro. Semarang.

Halim, Abdul. (2015). Manajemen Keuangan Bisnis : Konsep dan Aplikasinya. Jakarta : Mitra Wacana Media

Hartono. (2010). Teori Portofolio dan Analisis Investasi. Yogyakarta: BPFE, Edisi Keenam.

Hidayat, Rusdi. (2017). Pasar Keuangan Internasional. Surabaya: Zifatama Jawara

Kartini, Gatot Hermawan, "Economic Value Added dan Market Value Added terhadap Return saham pada Perusahaan Manufaktur yang terdaftar di BEI 2005-2006", (Jurnal Keuangan dan Perbankan, Vol. 12, No. 3 September 2008), Fakultas Ekonomi Universitas Islam Indonesia, Yogyakarta

Kasmir. (2013). Analisis Laporan Keuangan. Rajawali Pers : Jakarta.

Luke Suciyati Amna (Jurnal Akuntansi \& Keuangan: Vol. 11,No. 1, Maret 2020, ISSN: 2087-2054), dengan judul "Pengaruh Economic Value Added (Eva) Dan Market Value Added (Mva) Terhadap Return Saham".

Rudianto. (2006). Akutansi Manajemen. Jakarta: PT. Gramedia

Samsul, Mohammad. (2006). Pasar modal dan Manajemen Portofolio, Jakarta: Erlangga

Soehardi, S., Permatasari, D. A., \& Sihite, J. (2020). Pengaruh Pandemik Covid-19 Terhadap Pendapatan Tempat Wisata dan Kinerja Karyawan Pariwisata di Jakarta. Jurnal Kajian Ilmiah, 1(1), 114.

https://doi.org/https://doi.org/10.315 99/jki.v1i1.216

Sugiyono, (2013). Metode Penelitian Bisnis. Bandung: Alfabeta

Tjiptono Darmadji, Hendy M. Fakhruddin.
(2008). Pasar Modal di Indonesia Pendekatan Tanya Jawab. Jakarta : Salemba Empat

Wijaya, Harris H. dan Lauw Tjun-Tjun, “ Pengaruh Economic Value Added Terhadap Tingkat Pengembalian Saham pada Perusahaan yang Tergabung dalam LQ-45", (Jurnal Akuntansi, Vol. 1, No. 2, November 2009 hal.180) 